\title{
NOVO ATLAS DA EUROPA NO MUNDO
}

\author{
NUNO MARQUES DA COSTA ${ }^{1}$
}

O processo de mundialização tem vindo a ser estudado pelas diferentes ciências sociais e, naturalmente, pela Geografia. Apesar da emergência relativamente recente no discurso científico da Geografia, os trabalhos seminais de Braudel, Wallerstein ou Bairoch, foram desenvolvidos há mais de três décadas. Estes autores definiram o processo de mundialização como multisecular e geo-histórico, resultante da expansão progressiva do capitalismo no espaço mundial. Segundo eles, este processo foi produzindo distintos sistemas geopolíticos, geoestratégicos e geoeconómicos, conduzindo ao desenvolvimento de diferentes relações culturais e gerando distintos fluxos, redesenhando novas geografias e alterando o sucessivo posicionamento relativo dos países e dos blocos político-económicos, que entretanto foram surgindo.

Perceber e analisar o posicionamento da União Europeia, bem como os países no seu espaço de proximidade, no actual contexto mundial constitui a razão do Atlas de l'Europe dans le Monde. Fruto de um projecto de investigação no âmbito do ESPON (European Spatial Planning Observation Network), o trabalho, dirigido por Clarisse Didelon, Claude Grasland e Yann Richard, constitui uma profunda reflexão sobre a posição da União Europeia na (re)organização do espaço mundial na transição para o séculoXXI, na terceira fase do processo de mundialização, de economia mais liberal, de base financeira e menos regulada, segundo a mesma teoria da mundialização.

O atlas que nos é apresentado é constituído por um riquíssimo conjunto de mapas e de gráficos, sempre acompanhados por textos de análise que abordam o posicionamento da Europa relativamente à sua dimensão física, demográfica, comercial, económica e financeira, nas redes de transporte e de comunicação, em relação aos direitos humanos e à ajuda ao desenvolvimento, bem como das suas relações com os países limítrofes.

Dividido em seis partes e vinte e dois capítulos, este trabalho começa por discutir o melhor sistema de projecção cartográfica a utilizar na maior parte dos mapas. Não sendo uma discussão muito comum neste tipo de trabalhos, os autores analisam as vantagens e as desvantagens de diferentes sistemas de projecção, acabando por optar por uma, não muito comum neste tipo de trabalhos: projecção azimutal equidistante centrada no Pólo Norte. No entanto, apesar da dificuldade que um leitor menos preparado possa sentir na leitura dos

Recebido: Julho 2011. Aceite: Dezembro 2011.

1 Professor do Instituto de Geografia e Ordenamento do Território e Investigador do Centro de Estudos Geográficos da Universidade de Lisboa. E-mail: nunocosta@campus.ul.pt 
mapas, a escolha revela-se adequada à visão eurocêntrica revelada neste trabalho, realçando a posição da Europa no mundo.

Na primeira parte, mesmo antes de se colocar a questão da posição da União Europeia no mundo, é questionada a delimitação da Europa e o próprio conceito de continente europeu, uma vez que este continente nem sempre surge perfeitamente delimitado, tanto pela análise de diferentes variáveis, como na percepção individual dos europeus. No primeiro capítulo é analisada a posição da Europa no contexto mundial, a partir dos potenciais de superfície, de população e de riqueza mundiais, permitindo verificar, como afirmam os autores, que diferentes delimitações podem ser encontradas para a Europa. No segundo capítulo é discutida a importância relativa da União Europeia no mundo, em termos populacionais, de superfície e de produção de riqueza. No terceiro capítulo é analisada a posição da Europa de acordo com as divisões das grandes organizações internacionais e no quarto, como corolário da discussão sobre os limites da Europa, a sua delimitação mental a partir de um inquérito dirigido a especialistas europeus em ordenamento do território.

Na segunda parte é analisada a posição da Europa em relação às condições demográficas (capítulo 5), da sustentabilidade das tendências de evolução das suas estruturas demográficas (capítulo 6) e da relação demográfica com a produção de riqueza (capítulo 7). A perda de importância relativa em termos populacionais e a debilidade da sua estrutura demográfica constituem as principais conclusões, colocando-se também a questão da necessidade de reforçar a relação com os países ao Sul do Mediterrâneo.

A terceira parte analisa a posição da União Europeia no conjunto de trocas internacionais. Os autores mostram o papel central que a União Europeia assume no comércio internacional (capítulo 8), a relevância como investidor internacional (capítulo 9) e a sua posição como centro financeiro (capítulo 10), finalizando com a análise da posição da Europa relativamente ao auxílio ao desenvolvimento (capítulo 11). A principal conclusão desta parte revela que, para além do peso real da União Europeia na economia mundial, ela desenvolve um espaço de maior relação com países terceiros que ultrapassa mesmo o do antigo espaço colonial europeu.

A quarta parte analisa a posição da Europa nas redes mundiais de transportes e de comunicações. A importância que o transporte aéreo tem vindo a desempenhar no processo de mundialização conduziu à análise individualizada do tráfego aéreo (capítulo 12). A União Europeia constitui um dos grandes nós no tráfego aéreo mundial, a partir da rede aeroportuária, que não se limita às cidades situadas no topo da hierarquia urbana europeia, mas inclui outras cidades que se têm vindo a afirmar como importantes hubs nas ligações extra-europeias. Neste capítulo é ainda definida uma interessante tipologia dos aeroportos europeus, atendendo às ligações aéreas dominantes em cada uma das infra-estruturas aeroportuárias. No capítulo seguinte é discutida a posição da Europa como potência marítima. A importância da rede europeia de portos, a posição europeia no tráfego de carga contentorizada, a importância da sua frota e das ligações marítimas intra-europeias são amplamente analisadas neste capítulo. A posição da Europa nas redes de energia (capítulo 14) e nas redes de telecomunicações (capítulo 15) terminam esta parte.

A quinta parte é dedicada à análise da posição da Europa relativamente à salvaguarda dos direitos humanos (capítulo 16), do consumo e segurança alimentar (capítulo 17), da preservação ambiental e observância dos princípios de desenvolvimento sustentável (capítulo 18) e, por fim, do desenvolvimento humano, tendo como base o Índice de Desenvolvimento Humano da ONU (capítulo 19). A análise dos capítulos que compõem esta parte revela a posição de destaque que a União Europeia assume no capítulo do desenvolvimento humano e qualidade de vida, apesar das importantes disparidades internas. 
Na última parte deste atlas, os autores concluem que a União Europeia possui todo um conjunto de funções e de capacidades que lhe permitem polarizar uma parte significativa do espaço mundial, ilustrando essa capacidade através da análise dos fluxos turísticos (capítulo 20) e dos fluxos migratórios (capítulo 21). A União Europeia constitui o primeiro polo turístico mundial, tanto pela atracção externa como pelos fluxos gerados internamente. Para além dos importantes fluxos internos, a presença de turistas europeus é particularmente importante nos países que ficam na sua proximidade, contribuindo dessa forma não só para a integração europeia como também para a integração desses espaços de vizinhança, alargando o espaço de influência da Europa. Da mesma forma, os movimentos migratórios reflectem a posição central da Europa no processo de mundialização. A União Europeia constitui hoje o principal polo de atracção de emigrantes, apesar das diferentes posições assumidas pelos estados membros, ora abrindo as suas fronteiras por imperativo económico e por desajuste das suas estruturas demográficas, ora restringindo as entradas, seja por motivos securitários seja para justificar o equilíbrio social interno de cada estado membro. O último capítulo, o vigésimo segundo, constitui a síntese do trabalho, conseguida através da cartografia de cinco indicadores síntese, gerados a partir dos scores de uma análise em componentes principais, e de uma tipologia das relações e do tipo de influência da Europa no mundo. Os indicadores são: a proximidade potencial à União Europeia, a proximidade histórica e linguística, a proximidade definida pelas trocas comerciais, a proximidade definida pelas diferenças de desenvolvimento e pelas complementaridades demográficas e por um indicador sintético de influência global da União Europeia no mundo. A tipologia final define quatro grupos de países. O primeiro, o de integração, caracteriza os países de vizinhança imediata, com fronteiras comuns (Rússia, Ucrânia, Moldávia ...), ou separados por uma fronteira marítima menos expressiva (Marrocos, Argélia, Tunísia...), onde a proximidade física é reforçada pelas relações comerciais, pelos fluxos demográficos e pela polarização das ligações aéreas internacionais através dos hubs europeus. O segundo tipo, o da responsabilidade, inclui o espaço constituído pelos países da África sub-saariana, outrora espaço colonizado pelas potências europeias, e onde os laços se mantêm fortes, muito para além da proximidade linguística. $\mathrm{O}$ terceiro tipo, o do partenariado, inclui os países mais distantes do continente europeu e que partilham uma língua e uma história comuns. Neste caso as relações coloniais foram desenvolvidas de forma mais intensa e constituem, na maior parte dos casos, relações antigas, tendo-se verificado movimentos migratórios da Europa para esses países desde o século XVI até ao início do século XX. Encontram-se neste grupo não só países com níveis de desenvolvimento idêntico ou superior ao das antigas potências coloniais (Estados Unidos, Canadá, Austrália, Nova Zelândia) como também algumas das nações emergentes (Brasil, Índia, Argentina ...). O quarto e último grupo, o do desafio, é constituído por países localizados entre o Golfo Pérsico e a Ásia Oriental, onde a influência europeia é bastante atenuada. As diferenças linguísticas e culturais, bem como as relações comerciais claramente desfavoráveis à Europa, permitem considerar este espaço como o espaço de desafio para a Europa no contexto da mundialização.

Este atlas, para além da riqueza da informação e da análise, constitui igualmente um excelente exemplo técnico de cartografia e de tratamento de informação, reforçando a ideia de que mapas rigorosos e inteligentes podem constituir bons veículos de divulgação de informação. Este atlas constitui, assim, um instrumento de trabalho científico incontornável. 